\title{
An Attempt to Fill the Gap between the Architectural Studies and Conceptualization in Architectural Thesis Design Studio
}

\author{
Rahman Tafahomi \\ Department of Architecture, School of Architecture and Built Environment, College of Science and Technology, \\ the University of Rwanda, Rwanda
}

Received: October 20th 2021, Revised: November 26th 2021, Accepted: November 28th 2021.

Refer: Tafahomi, R., (2021), An Attempt to Fill the Gap between the Architectural Studies and Conceptualization in Architectural Thesis Design Studio, Journal of Design Studio, V.3, N.2, pp 175-190,

R. Tafahomi ORCID: 0000-0002-7172-1302,

DOI: $10.46474 /$ jds.1012778 https://doi.org/10.46474/jds.1012778

\begin{abstract}
The aim of this paper is to evaluate the application of a theoretical framework in the architecture thesis project to discover the effectiveness of the exercise on the thesis projects. It was common to observe that the students prepared the architectural thesis project with limited, unstructured, or disconnected studies to analysis, programming, and conceptualization phases. A theoretical framework model was tested to evaluate the effects on the learning outcomes of the students. The methodology of the research was designed based on structured observation and content analysis. The findings of the research reveal that the students perceive and understand the studies and the theoretical framework differently. The students demonstrated their theoretical framework with four categorical specifications including information, application, presentation, and communication. The information referred to data and structure of the organization, the application implied the relation between the data collection, analysis and other phases of the thesis project, the presentation illustrated how they applied graphical tools to illustrate the data, and communication revealed the interaction between the students and the panel of juries and participants. In conclusion, the theoretical framework connects the studies to the concept generation and opens a new door for the discussion of the architectural studies and lessons learnt between the panel of juries, the students, and peers. For an effective expectation from the theoretical framework outputs, detailed guidelines could harmonize the students' outputs due to the verieties of the application, interpretation, and demonstration of the architectural theoretical frameworks.
\end{abstract}

Keywords: Architecture Thesis, Theoretical Framework, Information, Application, Presentation, Communication.

\section{Introduction}

The thesis program in undergraduate studies is a key design activity to demonstrate the ability of the students in solving problems through design decisions (Ghonim \& Eweda, 2019). The thesis project is under influence of different factors to fulfill the task such as inspiration, analysis, and conceptualization phases (Tafahomi, 2021a). The thesis or final year project also widely was discussed as a process of problem-solving through studies, analysis, and design decisions by the students (Borden \& Ray, 
2006; Mauch \& Park, 2003). Although the thesis project is a student project, it is openly under influence of the juries, supervisors, and peer-students from the first stage (Tafahomi, 2021a) as a collective knowledge output (Borden \& Ray, 2006). Seemingly, the quality of a thesis project not only represent the students' skills and knowledge but also identifies the approach and methods of the department to train the students (Brown \& Renshaw, 2006; Mindrup, 2014).

According to the curriculum of the undergraduate program in architecture, students are supposed to do a thesis project as the final task to fulfill the program (DoF, 2014). The thesis is mentioned in the curriculum as a research-based design activity that continues for two semesters in one academic year, which is divided into thesis one and two. Although thesis two focuses on design development, thesis one has been divided into three modules including Research and Documentation, Project Programming, and Conceptualization. The curriculum expected studies, research, and analysis activities from the students although the content of the modules has less been detailed to lead the students for different activities in thesis processes. However, the thesis projects of the students could demonstrate that the results of the studies did less take into consideration seriously by both students and supervisors. The study identified that the students seriously followed the supervisors, module leaders, and the peer-students in the thesis process more in the 'personal procedure' than a systematic process (Tafahomi, 2021a, p. 15). Perhaps the gap took the place in the approach to observe the research activities in the thesis project.

There are two distinguishable approaches for the research and documentation activities in the department due to the background of the staff or the school of thought (Borden \& Ray, 2006). On the one hand, there is a group of staff, who assumes that the research activity refers to just redrawing of previous projects, in which the meaning of the architecture is just design (Drexler, 1975; Littmann, 2000; Tafahomi, 2021b). Therefore, doing research is to understand the precedents projects, especially the celebrated projects, which have been designed by the elite architects (Laroche, 2008; Littmann, 2000). This group of staff advocates the research and documentation in terms of the redrawing of precedents projects to inspire the students in the thesis project. This approach also was mentioned by Till in terms of 'architecture is just architecture' than research (Till, 2008, p. 1) and Frayling called 'research in' art and design (Frayling, 1993, p. 2). In this point of view, the architecture knowledge and skills are learnt through architecture study importantly the history, theory, and projects. This group of supervisors expects to see some clusters of redrawing in terms of study, research, and documentation based on the thesis topics such as school, hospital, or museum. They also recommend the students to start the conceptualization through drawing even before research and documentation to advocate a design-precedents-redrawing process.

On the other hand, there is another group of staff and supervisors who expected research activities by the students about the context and users to check the influential aspects of the design process. This group of staff expects to observe a systematic study by the students in the theory and literature to discover that last achieved knowledge in the architecture and technology to apply in the projects (Williams, 2018). This group encourages 
the students in the study process to enhance their drawing with logical aspects in the current debates about architectural theories. This group expects two clusters of information from the students including the results of the studies and the synopsis of the precedents projects. Groat and Wang mentioned this group of the researcher in terms of looking for new areas in the architectural demine (Groat \& Wang, 2002), which was emphasized by Till in terms of 'A Building as a Research' (Till, 2008 , p. 2). Nonetheless, the problem is how the students apply the results in the design process.

The gap is not just the difference between the two approaches in the thesis process. The curriculum also includes just one course with the title of architectural research methodology in the fourth year, which is supposed that the students catch up all missing aspects in the research through it (DoF, 2014). However, the students learn subjects in the department based on the theory with memorizing and final writing exam approach based on the precedents-redrawing-design circulation for design studios, which makes the students far from a process of the research and investigation (Tafahomi, 2021b). Despite the students doing research according to the advice of the lecturers, juries, or supervisors, application of the studies, research and documentation is a big gap in the department. In other words, it is common to observe that the students provide a strong part of the studies and investigation in the thesis activities; however, they can less apply the results in the thesis project. Therefore, the students put away the results of the study and start again the drawing and conceptualization from the beginning.

This result criticizes by both groups of the staff. It means despite the students doing research through other sources, the students start the design activities through sketching, drawing, redrawing based on the lessons learnt from previous years than their own research achievements in the thesis process. Therefore, the first group advocates doing research could possibly waste the time of the students in the academic year and make far them from design activities. This challenge in the department highlights a big gap in the application of the knowledge in the design process in terms of a theoretical framework for the design as the results of the studies in architecture.

In this background, it was hypothesized that by leading the students to represent a theoretical framework as a synopsis of the architectural studies, they could apply the lessons learnt in the design process to fill the gap. The research questions are defined as what is architectural studies in a thesis project, how the students accumulate the knowledge in this process, and what is a theoretical framework for an architectural thesis project? By saying that the main objective of this research is to evaluate the application of the theoretical framework in the study and research in the thesis activities in terms of learning outcomes of the students to fill the gap between the architectural studies and the conceptualization in the thesis projects.

\section{Arguments on the Architectural Studies and Theoretical Framework}

There is a wide range of arguments on the relations between architectural theory and practice, study and design, and architectural project and thesis. In addition, there is a variety of products for the students in architecture in terms of source of studies in an undergraduate thesis project such as history and theories, technology and graphics, and precedent projects. The theoretical sources have 
analyzed the architectural project through critics (Jencks, 2002; Ots, 2010; Lawson, 2004; Lawson, 2005), analysis (Clark \& Pause, 1996; Unwin, 2014), and interpretation (Mugerauer, 1995; Mugerauer, 2014; Lang J. , 1987) of the buildings to discover the theories beyond of the practice. The second cluster as graphic and technology was mentioned as the key elements to transfer the architectural knowledge. A variety of sources could list in this cluster such as architectural drawing (Ching, 1996; Ching, 2010; Ching, 2015), drawing as an expression of an idea (Crowe \& Laseau, 2011; Laseau, 2000; White, 1975), drawing as analysis (White, 1983; Regis, 2003; Sperlregen, 2003), and drawing standards (Neufert, 2012). All these clusters of architectural sources have attempted to deliver their own architectural understanding and interpretation of architectural theories and practices through texts, images, and drawing, which could be applied in architectural education and thesis projects.

For example, Mauch and Park (2003, p. 107) emphasized that all thesis and dissertation structures include a studies section to reveal a summary about the 'known and unknown' matters in the field of the study in terms of the theoretical aspects. They revealed that the theoretical and analytical approaches are applied at graduate and postgraduate theses more than undergraduate level. For this reason, they believed that different disciplines include varieties of thesis formats from a research dissertation to a monograph. For example, Bryman applied the work of theoretical framework to demonstrate the level of understating of theories of research in a scientific way (Bryman, 1988). In fact, the framework was applied to construct sets of theories that worked together to deliver the same meaning or supportive meaning of a total idea. In other words, the framework was implied on the theories or facts that work in a specific relationship to represent the epistemological approach (Groat \& Wang, 2002). Although the theoretical framework stays on the assumption of the researcher, this notion leads the research for the methodological tools and data analysis (Foddy, 2001). The construction of the theoretical framework could take place in the early of the research or at the end stage (Groat \& Wang, 2002).

Creswell (2018) introduced the theoretical framework in terms of philosophical assumption to define and set up knowledge in the research process that refers to the relation between data and theory. The study on the importance of the theoretical framework revealed that the frame leads the research to select appropriate methods and relevant data in the research process (Charmaz, Thornberg, \& Keane, 2018). Williams (2018) advocated a synthesis to extract the theoretical studies from the literature in the thesis writing. The study attempted to draw a guideline for the dissertation through an emphasis on the extraction of the relevant theoretical perspective in the logical structure to represent a new set of data to the reader. She recommended some diagrams to summarize and triangulate the different data in the logical presentation by the students. This synopsis of the data was included some level of interpretation by the students in terms of logical style (Borden \& Ray, 2006), a reflection of knowledge (Williams, 2018), or content analysis (Krippendorff, 2003), which presented an applicable format of a theoretical framework.

Bloomberg and Volpe (2019, p. 250) designed a guideline for the students to fulfill the dissertation in terms of the 'depository of knowledge' in the field. 
They highlighted the objective of the studies in a thesis project in terms of summative, integrated, and related achievement about the problem in the thesis that is needed to be solved through a creative and critical point of view. Therefore, the result of the study is to reformulate a dialogue in an articulated form to represent the assimilation of lessons learnt.

Frayling (1993, pp. 1-2) reclassified research in art and design into three categories including "research in, research through, and research for" art and design. He believed that the activities of designers are part of the research 'in or for' to support design, except what they do in the design studio. This classification referred to supportive learning through studies for the design activities in the specific discipline. Seemingly, a major part of the studies in architectural history and theory is part of the research in the architecture that has been structured based on the reviewing of the project and redrawing on the design.

Borden and Ray (2006) identified some common problems in architectural thesis writing that they have rooted in the writing of the history of architecture based on different points of view, importantly objectivity, iconology, Hegelian approach, and politicized history. They revealed that writing a piece of research, critics, or report about the architecture is dependent on the schools of thought and style of architecture training, which form the theoretical framework of the students in thesis writing. They argued that the architecture dissertation or thesis is not just drawing or image but the words that are going to explain the project through new ideas although generally students and staff take less into consideration the writing of the idea seriously. They also criticized the perspective of the schools to limit the architectural thesis into the design. To solve the problem, they recommended a wide range of possibilities for thesis projects such as materials, ideas, projects, theories, and technology.

Oxford dictionary defines the framework in terms of 'an essential supporting structure of a building, vehicle, or object' and 'a basic structure underlying a system, concept, or text' (Oxford, 2021). Cambridge dictionary mentions 'a supporting structure around which something can be built' or 'a system of rules, ideas, or beliefs that are used to plan or decide something' (Cambridge, 2021). The Collins dictionary develops the meaning to 'A framework is a particular set of rules, ideas, or beliefs which you use in order to deal with problems or to decide what to do' (Collins, 2021). Longman dictionary defined the theoretical formwork as 'a set of ideas that are used as a basis for understanding or doing something' (Longman, 2020, p. 911). These clusters of meanings refer to key factors to design a theoretical framework. The theoretical framework is a systematic achievement of data, ideas, or beliefs through a selecting process to deal with some problem in the specific field of study of research. This redefinition of the meaning of framework could refer to the challenge of the application of the theoretical studies in the practical project based on the self-selection of the students. The important point of this interpretation of the meaning is to accept different interpretations of the students in the design process of their own theoretical framework based on the intended selection.

In a summary, the theoretical framework not only has been absent in the module description of the curriculum but also this topic less has been highlighted in the 
profession (Bae, Bhalodia, \& Runyan, 2019). The main objective of a theoretical framework in the thesis projects is presenting the synopsis of knowledge (Williams, 2018) in a specific topic free of presupposition and bias (Borden \& Ray, 2006). This knowledge presents through integrated elements and aspects to create a whole picture of the thesis to lead the researcher to tackle the research problems (Bloomberg \& Volpe, 2019). The theoretical framework is based on the personal selection of the thesis writer to include the key factors and aspects in an architectural design project. The key factors are both known and unknown (Mauch \& Park, 2003) aspects of knowledge that are supposed to apply in the research process for analysis, implementation, and application. The key elements in the theoretical framework include the architectural components and subcomponents that the composition of those components create a specific style of design in the project. The architectural key components represent the common technical skills of the students, which is advocated in terms of graphical features and techniques to communicate with the juries and the readers.

\section{Method and Materials}

This section includes the methodology of the research in terms of exposing the methods in the similar research, the research design to express how the methods were applied in the research, research process, data specification, limitation and implication, and the context of the study as the time and location.

\section{Methodology}

The studies applied quantitative and qualitative methods to study the students' behaviors and education specifications (Cohen, Manion, \& Morrison, 2007; Frey,
2018). Despite the advantages of the quantitative methods based on the questionnaire and big data, qualitative methods were applied widely in the case of the architectural studies (Groat \& Wang, 2002; Niezabitowska, 2018; Silverman, 2004) such as content analysis (Krippendorff, 2003; Silverman, 2010), structured observation (FrankfortNachmias, Nachmias, \& DeWaard, 2014; Tafahomi \& Nadi, 2020; Tafahomi, 2020), graphical analysis (Tafahomi, 2020; Tafahomi, 2021b; Tafahomi, 2021c). This kind of research is also mentioned as a supportive system in architecture to bring other knowledge in the architecture areas for the application (Frayling, 1993).

The content analysis was applied in the built environment research such as development plans (Carmona, 2001; Lang J., 2005), policies (APA, 2006), theoretical debates (Lang J. , 1987), and even for the content of the exam and pedagogy (McConnell \& Doolittle, 2012). The study revealed that all the content analysis activities include some level of interpretations in the outputs (Krippendorff, 2003). The content analysis was not limited to the text rather than the graphical features have been included in such kind of analysis (Attoe, 1979; McClean \& Hourigan, 2013; Boults \& Sullivan, 2010). The structured observation was applied in behavioral studies of users (Bonnes \& Bonaiuto, 2002) in the built environment studies to observe the specific behaviors or reactions in the context (Tafahomi \& Nadi, 2020; Tafahomi, 2021d).

\section{Research Design}

A qualitative approach (Groat \& Wang, 2002; Neuman L. W., 2006; Niezabitowska, 2018; Silverman, 2010) with relevant techniques importantly structured observation and content analysis 
were selected to carry out the research on the behavioral pattern of the students and staff (Tafahomi \& Nadi, 2020; Tafahomi, 2021c) and the architectural thesis design products. The structured observation was applied to observe systematically the students' presentation (Tafahomi, 2021b) in the arrangement of the design boards and the staff reactions about the contents to find out the results of the studies for the development of the thesis projects. In addition, the content analysis was applied to analyze and interpret (Tafahomi, 2021e) the thesis booklet productions in terms of the summary of the lessons learnt and the extraction of the ideas through critical thinking. Through this cluster of information, the research evaluated the specifications of the application of the studies in the thesis project.

\section{Research Process}

The results of the studies in terms of the theoretical framework of the students was evaluated in both design boards presentations and thesis booklet preparation in both formative and summative assessments that calls as CAT (Continue Assessment Testing). It was asked that the students do an evaluation on the studies at the end of the section in terms of the theoretical framework based on the comparison, critics, selection of the logical ideas about the architectural thesis project. They were free to apply either text to demonstrate their own conclusion about the studies or use diagrams, tables and graphs to represent the main lesson learnt through the architectural studies. In the structured observation, the application of the theoretical framework as the results of the studies was examined through the architectural design boards' presentation by the students and the reactions of the juries. Then, the research applied the content analysis to discover the application of synthesis of the studies in terms of a clear conclusion, summary, or theoretical framework in the thesis project of the students to evaluate the key factors of the lessons learnt, which represented the architectural components and subcomponents for the design project. It was supposed that the students highlight the main architectural components and subcomponents in terms of architectural criteria and indicators for the design in the theoretical framework that was significant in their own thesis projects such as lighting, transparency, or porosity.

\section{Data Specification}

The data of the research were collected through the behavioral patterns of both students, juries, and produced materials through the architectural design boards and the thesis booklet. Data were collected through the contents and graphical presentations of the students and the attention of the juries to data in the architectural thesis design studio. Therefore, data were mentioned by the students in three major categories including texts, diagrams, and tables in both architectural design boards and the thesis booklet. The target group included 22 final year students who registered in the thesis module to fulfill the thesis project requirements for graduation.

\section{The Context of Study}

The research took place in the first semester 2019-2020 academic year, in the department of architecture at the University of Rwanda. The location of the research was arranged in the thesis design studio on the second floor of the school of architecture and built environment (SABE). The studio was included 22 thesis students in the fifth-year of the study including 3 females and 19 males.

The panel of the juries combined from the 10 academic staff six $\mathrm{PhD}$ and 4 master 
holders who graduated from different schools of thought in architecture importantly, Polytechnique in Italy, and universities in Nigeria, and eclectic styles in Kenya, Uganda, and Iran.

The studies revealed that the schools of the through have played a significant role in the architecture education to design the courses, methods of delivery, and thesis project importantly, Beaux Art, Polytechnique, and Bauhaus traditions due to the level of art, science, and craft in the design process (Littmann, 2000; Mindrup, 2014; Madanovic, 2018; Tafahomi, 2021a). Despite the root of schools of thought in Europe, the structure of the thought in the format of the curriculum was copied, adapted, localized, specialized, and integrated into different contexts and times by the followers. For this reason, some schools of thought could be observed more predominated in some counties based on the educated people in the position of educators. Nonetheless, the schools of thought have been faced the transformation, modification, and integration based on multifactor importantly the context. The results of the process created an eclectic style that included some aspects of the schools. As an example, the study took the place in East Africa with a curriculum that was borrowed from another country in the region based on the adaptation to the context with both similar and dissimilar aspects of schools of thought in the structure of a curriculum.

\section{Results}

The architectural design boards of the students included A0 posters in the vertical format including all activities of the students such as the architectural problems statements, the design objectives, studies, and the theoretical frameworks. The students applied the graphical techniques and feature to present their studies on the drawing boards. Therefore, both supervisors and juries expected to observe the theoretical frameworks in the boards in terms of the synopsis of the lessons learnt in the study process. The students presented the theoretical frameworks with a wide range of variety.

In detail, the students presented the architectural theoretical framework in design boards importantly with three styles. The first group of students presented the theoretical framework and the architectural components in text format on the boards with different sizes, colors, and bolded words to emphasize the importance of the architectural components. Second group presented in a table format including architectural components and subcomponents but without their own logical argument about the relationships. The last group illustrated the architectural components and subcomponents in the diagram with the graphical feature to present their logic, interconnection, and importance. However, the major parts of the students applied either table format or graphical features in second and third CAT, which revealed that the students learnt through peer-presenter how they can be more effective in the presentation of the studies boards.

It was requested that the students present also their own theoretical frameworks in the thesis booklet based on the architectural topics. It was also requested to apply citation and reference for the applied sources such as online, library, or journal materials. The studio coordinator and supervisors were the person in charge to read the students products and adding comments on different drafts of thesis drafts. 
The students presented the theoretical frameworks in the thesis booklet differently. First, some of the students just presented some of the precedents projects from online sources including photos and some general information. They attempted to introduce some similar projects to the thesis topic to get inspiration from those projects. Second, the students did some studies on the architecture theory and history to introduce topics in line with the thesis projects particularly due to the context and the users. However, the theoretical framework did not present separately and was integrated with studies or precedents studies. Third, this group of students presented the studies, precedents studies, and the theoretical framework in a process. However, the theoretical framework for them was a summary of the studies rather than results of a critical view. The fourth group of the students presented theoretical frameworks in the requested format and added the architectural components and subcomponents. Despite the structure of the extraction being right, the architectural components and subcomponents did not link to the studies, precedents, or logical arguments. Just one group of the students as the group fifth presented an integrated and logical structure that represented a deep understanding of the task and activity. It meant, the students did studies about the thematic aspects of the thesis project, they analyzed precedents projects to discover the important aspects of the design, and they evaluated and extracted the significant architectural components and subcomponents in the theoretical frameworks that were so important to proceed the thesis project. This group applied tables, graphical features, and diagrams to illustrate the relation between the main architectural components, subcomponents, and sources.
Observation of the behavioral patterns of the panel of the jury including supervisors, staff, and visitors highlighted that they took into consideration the theoretical framework in different ways. First, some of the members did not pay attention to the theoretical framework presentation but just the drawing parts to discover how the students redrew the precedents projects as the assimilation of design ideas. The second group observed the architectural components and subcomponents in terms of the areas of interest of the students or design objectives in the projects. Therefore, they paid more attention to the achievability of the components than the logical process of the conclusion. The third group understood the architectural components and subcomponents as key factors for the development of the projects and they attempted to question, comment, and develop the key components. Therefore, this group encouraged the students to develop the theoretical frameworks in detailed aspects of the architectural components and subcomponents to address specific actions for the design stage.

\section{Analysis of the Results}

The students perceive and interpret differently the theoretical framework and the architectural components in the process of the study and design although they have a similar training process. It means that the students take into account the architectural components in terms of either the final achievement of the design studies or the key aspects to evaluate and apply in the design process with modification. The results identify that the students have their own interpretation and understanding of the theoretical framework and the architectural components and subcomponents and they personalize and specialize it for their own purposes. The understanding of the students about the 
theoretical framework could be classified two levels and in four key aspects including sets of information, application of data for analysis and design, the way of presentation, and technique for communication in thesis studies. Figure 1 show this relationship.

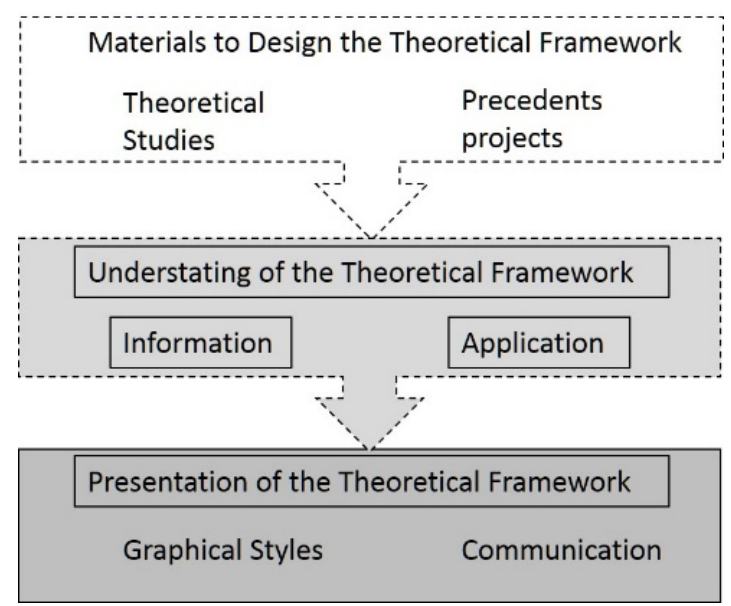

Figure 1: the key aspects to demonstrate the theoretical framework

The students demonstrate different clusters of information as the lessons learnt through studies with the specific purpose of the application of the architectural elements and components in the design process. They arranged the architectural components, subcomponents with the references and years of the publication as the essential information in tables to support their achievements and to enhance the level of connection of their design proposal with the current architectural theory and practices. The students also apply tables, diagrams, figures to illustrate the importance of the achievements in the study process. These techniques attempt to represent their own information about the essential and key factors in architectural studies in relation to the thesis topic.

The students also understood the theoretical framework as a repository to collect data through studies to apply in three stages such as data, analysis, programming, conceptualization and design. The students presented the key criteria in the way to show earlier findings as the lessons learnt through of the students although some of the examples of the presentations referred to the analytical activities projected to do in the analysis stage. Nonetheless, important aspects of the presentation by this group of students demonstrate the application of data in the design process than the information itself. For this group of students, the studies provide the rough material for the activities in the thesis process. They observe the architectural components as important factors that are supposed to adapt to the design project through examination and evaluation. This approach helps them to keep study, research, analysis, and transformation of the architectural components to the projects (Figure 2).

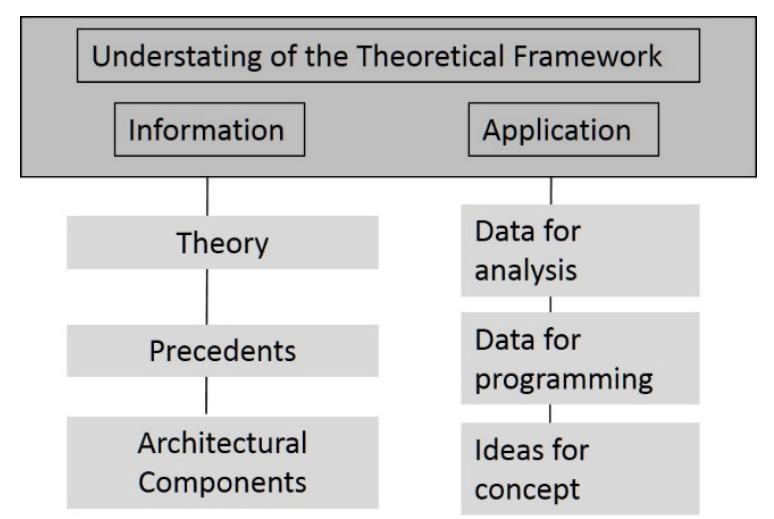

Figure 2: Two styles of Understanding of the Theoretical Framework

The students applied three techniques to present their own understanding of the theoretical framework in both the boards' presentation and the thesis booklet including graphs and diagrams, tables and texts, and sketches and photos. They used the graphs and diagram as a template to fill by the studies and the precedents studies. Those diagrams demonstrate that the students were familiar with the linear and the hierarchical diagrams more than other 
formats. The table is a common way to summarize the information in terms of their own understanding of architectural studies and the precedents projects in the table. The table included the name of the architectural elements and components, detailed aspects, and source of data. In the third technique, the students prefer to show their understanding of the theoretical framework.

Those techniques create opportunities for the students to communicate with the jury, peers, and self. Any style of presentation makes a particular way of communication with the participants. The students learnt to improve the presentation and techniques through the comments of the jury. This communication not only improved the presentation of the students in the next critics' time but also helped the student to understand the important points of their own works based on the critics and comments, and discussions. This process increases the level of self-understanding of the architectural project by the students directly. The communication also includes some indirect effects on the students' presentation and communication through observation of works of other students. The students learn continuously from previous experience to perform better in the next presentation. In fact, the feedback of the juries and other students lead them to do a self-evaluation to enhance the quality of the presentation and communication for the lessons learnt in the architectural studies phase (Figure 3).

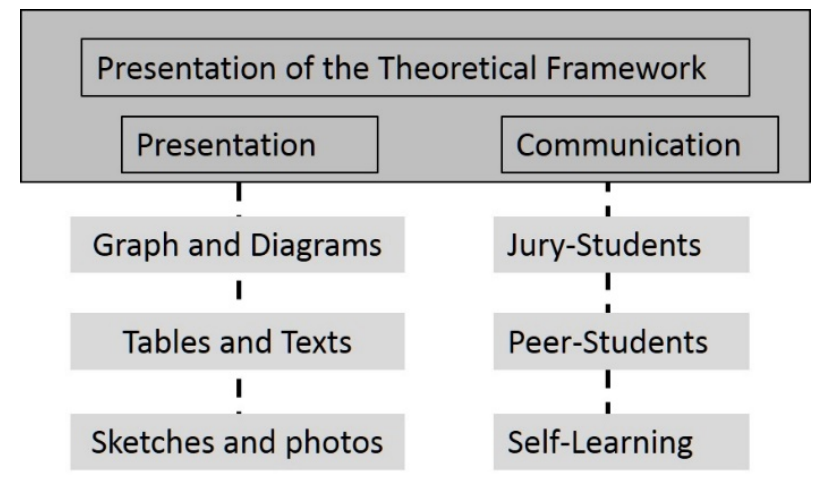

Figure 3: Presentation of the theoretical framework

\section{Discussion}

The results of the research identified that the students took into consideration the meaning of the theoretical framework as either a learning achievement or rule to plan how to deal with the architectural problem in the line with some definitions (Collins, 2021; Cambridge, 2021). Despite the instruction of the thesis referred to the criticizing and evaluating of the facts and data, the students applied the theoretical framework based on their own selection that the results were in the opposite of the finding of (Williams, 2018; Bloomberg \& Volpe, 2019) as critics. The students presented more what they have known in the process of the studies than questioning the missing aspect of knowledge as unknown matters (Mauch \& Park, 2003). Therefore, the students followed the methods as mentioned synopsis and summary (Williams, 2018) of the information in a logical process.

The students applied both content analysis and interpretation (Krippendorff, 2003; Borden \& Ray, 2006) in the presentation of the theoretical framework. Despite the absence of the critical point of view in the presentation of the students, they applied summative, integrated, and related sources (Bloomberg \& Volpe, 2019) to support their idea about the architectural components in terms of reflection of the 
lessons learnt (Williams, 2018) to deal with the architectural problems (Borden \& Ray, 2006), studies (Cohen, Manion, \& Morrison, 2007), and conceptualization (Tafahomi, 2021b). The students preferred to exemplify the studies through images and graphics to refer to the precedents studies as the lessons learnt without differentiation between of the research 'in or for' architecture that advocated by Frayling (1993). It means that the students applied different approaches to discover their own theoretical framework than a structured research process (Tafahomi, 2021a). They also were so interested in precedents studies than theoretical topics (Borden \& Ray, 2006) in the presentation that made their works more graphical than critical.

The students learnt continuously through their own presentation and communication to improve the theoretical framework that this achievement of the research has been less discussed by the studies (Bloomberg \& Volpe, 2019; Borden \& Ray, 2006; Tafahomi, 2021a). Although the studies revealed and advocated a linear process between the studies and the students to select, integrate, and present the results of the studies, the findings highlighted that the students were learnt through following the peer-learner in the presentation to borrow data and styles for effective communication (Frey, 2018; Tafahomi, 2021b). The results identified that the students improved information, application, presentation, and communication in a circular process that observing of design board presentation of other students was so effective in this process.

\section{Conclusion}

The students personalize instructions in the learning process to discover the most effective style for their achievements. They demonstrated four specifications including information, application, presentation, and communication to develop the theoretical framework in the thesis activities. Although it was requested from the students to extract the significant architectural components and subcomponents to present their own theoretical framework due to the instruction, the students reacted differently. The information in the theoretical framework is included in a spectrum of meanings and purposes for students to present their studies, interest areas, key factors, elements, or technology. This differentiation demonstrates that the students understand, interpret, personalize, and specialize the learning objective with a wide range of variety. Nonetheless, the theoretical framework and the architectural components and subcomponents consumed much more time from the students and it needs to take into consideration for the thesis modules.

The exercise could draw a strong link between the architectural studies and other stages in architecture design studios and particularly the thesis project importantly the analytical and conceptual phases. However, the students personalize this step in their own way of understanding of the thesis project. Therefore, the exercise demonstrates varieties of understanding, interpretation, presentation, and communication due to the theme of the thesis project, sources of the study, graphical ability, and priorities. It could increase the possibility of the differentiation and verities particularly when the students have different panels of the jury to evaluate the design boards' arrangement. Although the students presented the theoretical framework differently, participation in the presentation of other students inspires them to pay more attention to the 
presentation, communication, and interaction with the panel of juries. This participation provides an opportunity to learn directly and indirectly from both positive and negative aspects of the presentation of other students to improve their understating.

However, the application of the results in the department with the traditional style of the final year project could limit the achievements of the theoretical framework learning outcomes. In some departments, the instructors prefer to follow the traditional style of activities particularly redrawing from precedents studies in terms of the final project. This style results in minimizing of activities of the students in thesis study such as less study on the theoretical aspects, separated theories, and without criticizing the current knowledge. Perhaps, effective instructions for the theoretical framework in the thesis module could lead both staff and students to restructure the thesis learning outcomes based on the critical perspective, exploration of the unknown, and integration of point of view.

\section{References}

APA, A. (2006). Planning and urban design standards. New Jersey: John Wiley and Sons Inc

Attoe, W. O. (1979). Theory, criticism, and history of architecture. In A. Snyder, \& A. J. Catanese (Eds.), Introduction to Architecture (pp. 21-45). New York: McGraw-Hill Book Company.

Bae, S., Bhalodia, A., \& Runyan, R. C. (2019). Theoretical frameworks in interior design literature between 2006 and 2016 and the implication for evidence-based design. The Design Journal, 22(5), 627-648.

Bloomberg, L. D., \& Volpe, M. (2019). Completing your qualitative dissertation: a road map from beginning to end. Los Angeles: SAGE.

Bonnes, M., \& Bonaiuto, M. (2002). Environmental psychology: From spatialphysical environment to sustainable development. In R. B. Bechtel, \& A. Churchman (Eds.), Handbook of environment psychology (pp. 28-54). New York: John Wiley \& Sons, Inc.

Borden, I., \& Ray, K. R. (2006). The dissertation: An architecture student's handbook. (Second, Ed.) New York: Architectural Press, Elsevier.

Boults, E., \& Sullivan, C. (2010). Illustrated history of landscape Design. New Jersey: John Wiley \& Sons, Inc.

Brown, R., \& Renshaw, P. (2006). Positioning students as actors and authors: A chronotopic analysis of collaborative learning activities. Mind, Culture, and Activity, 13(3), 247-259. https://doi.org/10.1207/s15327884mca1303_6

Bryman, A. (1988). Quantity and quality in social research. London: Routledge .

Cambridge. (2021). Cambridge dictionary online. Cambridge: Cambridge. Retrieved from

https://dictionary.cambridge.org/dictionary/eng lish/framework

Carmona, M. (2001). Housing design quality: through policy, guidance and review. London: Spon Press.

Charmaz, K., Thornberg, R., \& Keane, E. (2018). Evolving grounded theory and social justice inquiry. In N. K. Denzin, \& Y. S. Lincoln, The SAGE handbook of qualitative research (pp. 720-776). London: SAGE.

Ching, F. D. (1996). Architecture, form, space, order. New York: Architectural Press.

Ching, F. D. (2010). Design drawing (2th ed.). New Jersey: John Wiley \& Sons, Inc. 
Ching, F. D. (2015). Architectural graphic (6 ed.). New York: Willy.

Clark, R. H., \& Pause, M. (1996). Precedents in architecture. New York: Van Nostrand Reinhold.

Cohen, L., Manion, L., \& Morrison, K. (2007). Research methods in education. New York: Routledge.

Collins. (2021, March 8). collinsdictionary.com . Retrieved from framework:

https://www.collinsdictionary.com/dictionary/e nglish/framework

Creswell, J. W., \& Creswell, D. J. (2018). Research design, qualitative, quantitative, and mixed methods approaches. London: SAGE Publications, Inc.

Crowe, N., \& Laseau, P. (2011). Visual notes for architects and designers (2 ed.). Wiley.

DoF. (2014). Architecture program specification. Kigali: the University of Rwanda.

Drexler, A. (1975). The architecture of the Ecole des Beaux Arts. New York: The Museum of Modern Art.

Foddy, W. (2001). Constructing questions for interviews and questionnaires: theory and practice in social research. Cambridge: Cambridge University Press.

Frankfort-Nachmias, C., Nachmias, D., \& DeWaard, J. (2014). Research methods in the social sciences (8 ed.). New York: SAGE Publisher Ink.

Frayling, C. (1993). Research in art and design. Royal College of Art Research Paper, 1(1), 1-5.

Frey, B. B. (2018). The SAGE encyclopedia of educational research, measurement, and evaluation. New York: SAGE.
Ghonim, M., \& Eweda, N. (2019). Instructors' perspectives on the pedagogy of architectural graduation projects: A qualitative study. Frontiers of Architectural Research, 8, 415427. https://doi.org/10.1016/j.foar.2019.01.007

Groat, L., \& Wang, D. (2002). Architectural research methods. New York: John Wiley \& Sons INC.

Jencks, C. (2002). The new paradigm in architecture: The language of postmodernism. New Haven, Connecticut: Yale University Press.

Krippendorff, K. H. (2003). Content analysis: An introduction to its methodology (2 ed.). New York: Sage Publications.

Lang, J. (1987). Creating architectural theory: The role of the behavioral sciences in environmental design. New York: Van Nostrand Reinhold.

Lang, J. (2005). Urban design: A typology of procedures and products. London: Architectural Press.

Laroche, D. (2008). The relationship between the Beaux-Arts school and the French school at Athens. 100 years with Danish architect at l'École française d'Athènes, Monographs of the Danish Institute at Athens. 13, pp. 11-17. Athens: Danish Institute at Athens.

Laseau, P. (2000). Graphic thinking for architects and designers (3th ed.). New York: Wiley.

Lawson, B. (2004). What designers know. Oxford: Architectural Press.

Lawson, B. (2005). How designers think: The design process demystified (4 ed.). Oxford: Oxford Press.

Littmann, W. (2000). Assault on the Ecole: Student campaigns against the Beaux Arts, 1925-1950. Journal of Architectural Education, 53(3), 159-166. 
Longman. (2020). Longman Collocations Dictionary and Thesaurus. Longman .

Madanovic, M. (2018). Persisting Beaux-Arts practices in architectural education: history and theory teaching at the auckland school of architecture, 1927-1969. Interstices Auckland School Centenary Special Issue, 9-24.

Mauch, J. E., \& Park, N. (2003). Guide to successful thesis and dissertation: a handbook for students and faculty. New York: Marcel Dekker, Inc.

McClean, D., \& Hourigan, N. (2013). Critical dialogue in architecture studio: Peer interaction and feedback. Journal for Education in the Built Environment, 8(1), 35-57. https://doi.org/10.11120/jebe.2013.00004

McConnell, K. D., \& Doolittle, P. E. (2012). Classroom-Level Assessment: Aligning Pedagogical Practices to Enhance Student Learning. In C. Secolsky, \& B. D. Denison, Handbook on measurement, assessment, and evaluation in higher education (pp. 15-30). Routledge.

Mindrup, M. (2014). Translations of material to technology in Bauhaus architecture. Wolkenkuckucksheim Internationale Zeitschrift zur Theorie der Architektur, 19(33), 161-172. Retrieved from cloudcuckoo.net/fileadmin/issues_en/issue_33/articl e_mindrup.pdf

Mugerauer, R. (1995). Interpreting environments: Tradition, deconstruction, hermeneutics. Texas: University of Texas.

Mugerauer, R. (2014). Interpreting nature: the emerging field of environmentalhermeneutics. Robert: Fordham University Press.

Neufert, E. (2012). Architects' Data . Oxford : Blackwell.

Neuman, L. W. (2006). Social research methods: Qualitative and quantitative approaches. New York: Pearson Education.
Niezabitowska, E. D. (2018). Research methods and techniques in architecture. New York: Routledge.

Ots, E. (2010). Decoding theory speak: An illustrated guide to architectural theory. Routledge.

Oxford. (2021). Oxford dictionary online. Oxford: Oxford. Retrieved from https://www.google.com/search?q=meaning + o $\mathrm{f}+$ framework\&rlz=1C1CYCW_enRW831RW 831\&oq $=$ meaning + of + framework \&aqs $=$ chrom e.69i57j019.10955j1j15\&sourceid=chrome\&ie $=\mathrm{UTF}-8$

Regis, R. (2003). Sketchbook: Piazza di Spagna, Rome. In D. Watson, A. Plattus, \& R. Shibley, Time saver standards for urban design (pp. 441-448). New York: Mc Grow Hill.

Silverman, D. (2004). Qualitative research: Theory, method and practice. New York: SAGE Publications Ltd.

Silverman, D. (2010). Doing qualitative research. New York: SAGE Publisher.

Sperlregen, P. D. (2003). Making a visual survey. In D. Watson, A. Plattus, \& R. Shibley, Time saver standards for urban design (pp. 431-440). New York: Mc Grow Hill.

Tafahomi, R. (2020). Educational outcome of students' group-table arrangement for collaboration in architecturalthesis studio. LWATI: A Journal of Contemporary Research, 17(2), 22-46.

Tafahomi, R. (2021a). Insight into a personalized procedure of design in concept generation by the students in architecture thesis projects. Journal of Design Studio, 3(1), 5-18. https://doi.org/10.46474/jds.910234

Tafahomi, R. (2021b). Learning activities of the of students in peer-jury practices in the architecture design studio. AKSARA: Jurnal Ilmu Pendidikan Nonformal,, 7(3), 795-814. https://doi.org/10.37905/aksara.7.3.795-814. 
Tafahomi, R. (2021c). Effects of the wallfaced seating arrangement strategy on the behavioural patterns of the students in the architecture thesis design studio. Asian Journal of Assessment in Teaching and Learning, 11(1), 85-97.

https://doi.org/10.37134/ajatel.vol11.1.8.2021

Tafahomi, R. (2021d, February). Application of physical and nonphysical elements in the conservation of historic core of city. South African Journal of Geomatics, 10(1), 75-86. https://doi.org/10.4314/sajg.v10i1.6

Tafahomi, R. (2021e). The Behavioral Patterns of the Student in the Position of Peer-Jury in Landscape Design Studio. EDUCATUM Journal of Social Science, 7(2), 57-65. https://doi.org/10.37134/ejoss.vol7.2.6.2021

Tafahomi, R., \& Nadi, R. (2020). Derivation of a design solution for the conservation of a historical Payab in the Redevelopment of Doloeei, Gonabad. International Journal of Built Environment and Sustainability, 7(1), 19. https://doi.org/10.11113/ijbes.v7.n1.407

Till, J. (2008). Three myths and one model. Building Material, 17, 4-10. Retrieved from https://jeremytill.s3.amazonaws.com/uploads/p ost/attachment/34/2007_Three_Myths_and_On e_Model.pdf

Unwin, S. (2014). Analysing architecture (4 ed.). New York: Routledge.

White, E. T. (1975). Concept sourcebook: a vocabulary architectural forms. Tucson: Architectural Media Ltd.

White, E. T. (1983). Site analysis: Diagramming information for architectural design. Tallahassee, Florida: Architectural Media Ltd.

Williams, K. (2018). Planning your dissertation. London: Red Globe Press. 